\title{
Macroamylasemia; a Dilemma in Morbidity
}

\author{
Onur Sakallığlu
}

Department of Pediatrics, Başkent University Zübeyde Hanım Training and Research Hospital, İzmir, Turkey

To the Editor,

A one-year-old boy was referred for randomly detected hyperamylasemia. Physical examination was completely normal, including growth parameters. Medical history and family history were unremarkable. In laboratory, the repeated serum amylases were found elevated with the values of $280 \mathrm{IU} / \mathrm{mL}, 290 \mathrm{IU} / \mathrm{mL}$ and $310 \mathrm{IU} / \mathrm{mL}(\mathrm{N}: 10-90 \mathrm{IU} / \mathrm{mL})$ together with a lower urine amylase level of $10.5 \mathrm{IU} / \mathrm{mL}$ (N: $25-500 \mathrm{IU} / \mathrm{mL}$ ). The complete blood count, acute-phase reactants, liver-renal-thyroid functional tests, serum lipase and immunoglobulins were normal. Antibodies against endomysium, gliadin, thyroglobulin, thyroid peroxidase, nucleus and dsDNA were negative. Abdominal ultrasonography and computed tomography (CT) scans were normal. According to these normal findings, hyperamylasemia due to macroamylasemia (MA) was found in patient. An informed consent form to research was obtained from parents. At analysis for MA, a precipitated activity was $87 \%$ at polyethylene glycol (PEG) precipitation (MA>60\%) (1).

Macroenzymes are complexes of serum enzymes commonly with immunoglobulins or lipoproteins that have a higher moleculer weight. Macroamylase is the most common macroenzyme, in which pancreatic or salivary amylase binds to plasma proteins and cannot be excreted by renal glomeruli. Macroamylasemia may be seen either isolated or associated with a variety of disorders, such as IgA deficiency, celiac disease, lymphoma, carcinoma, systemic lupus erithematosus, rheumatoid arthritis, liver disease and various autoimmune diseases (2-4). The pathogenesis of macroenzyme formation in these diseases is estimated by 'antigen-driven' theory: a self-antigen is altered or released from a sequestered site in the body and cross-reacts with an antibody initially formed against a foreign antigen. A second theory is the 'dysregulation of immune tolerance, which is likely to occur in autoimmune disorders (4). The cross-reactivity to either glutenrelated or other antigens resulting in autoantibody formation against pancreatic serum amylase at intestinal level is considered (5). The elevated serum amylase, low 24-hour urine amylase and reduced ratio of amylase clearance / creatinine clearance are im- portant at diagnosis. It has been shown that PEG precipitation is also a precise method in the detection of MA by purifying protein from macromolecules more easily and quickly (1). Due to the problem at urine collection, PEG precipitation was preferred in this case. It was considered as isolated MA due to the absence of associated disorders. In conclusion, MA is generally a benign condition, but associated potential disorders should be considered at follow-up. The case highlights the dilemma of additional invasive explorations and unnecessary treatments by differentiating MA from other situations associated to hyperamylasemia.

\section{Ethics Committee Approval: N/A.}

Informed Consent: Written informed consent was obtained from patient's parents who participated in this study.

Peer-review: Externally peer-reviewed.

Conflict of Interest: No conflict of interest was declared by the authors.

Financial Disclosure: The authors declared that this study has received no financial support.

\section{REFERENCES}

1. Davidson DF, Watson DJ. Macroenzyme detection by polyethylene glycol precipitation. Ann Clin Biochem 2003;40:514-20. [CrossRef]

2. Türkçapar N, Ozden A. Macroenzymes. Güncel Gastroenterology 2005;9:161-6.

3. A. Torrent Vernetta, O. Segarra Canton. Macroamylasemia in Peadiatrics. An Pediatr (Barc) 2008;69:439-41. [CrossRef]

4. Türkçapar N, Ozyüncü N, Idilman R, Ensari A, Soylu K, Ozden A. Macroamylasemia in a patient with selective IgA deficiency and antiphospholipid antibodies. Turk J Gastroenterol 2006;17:140-3.

5. Barera G, Bazzigaluppi E, Viscardi M, Renzetti F, Bianchi C, Chiumello $\mathrm{G}$, et al. Macroamylasemia attributable to gluten related amylase autoantibodies: A case report. Pediatrics 2001;107:E93. 